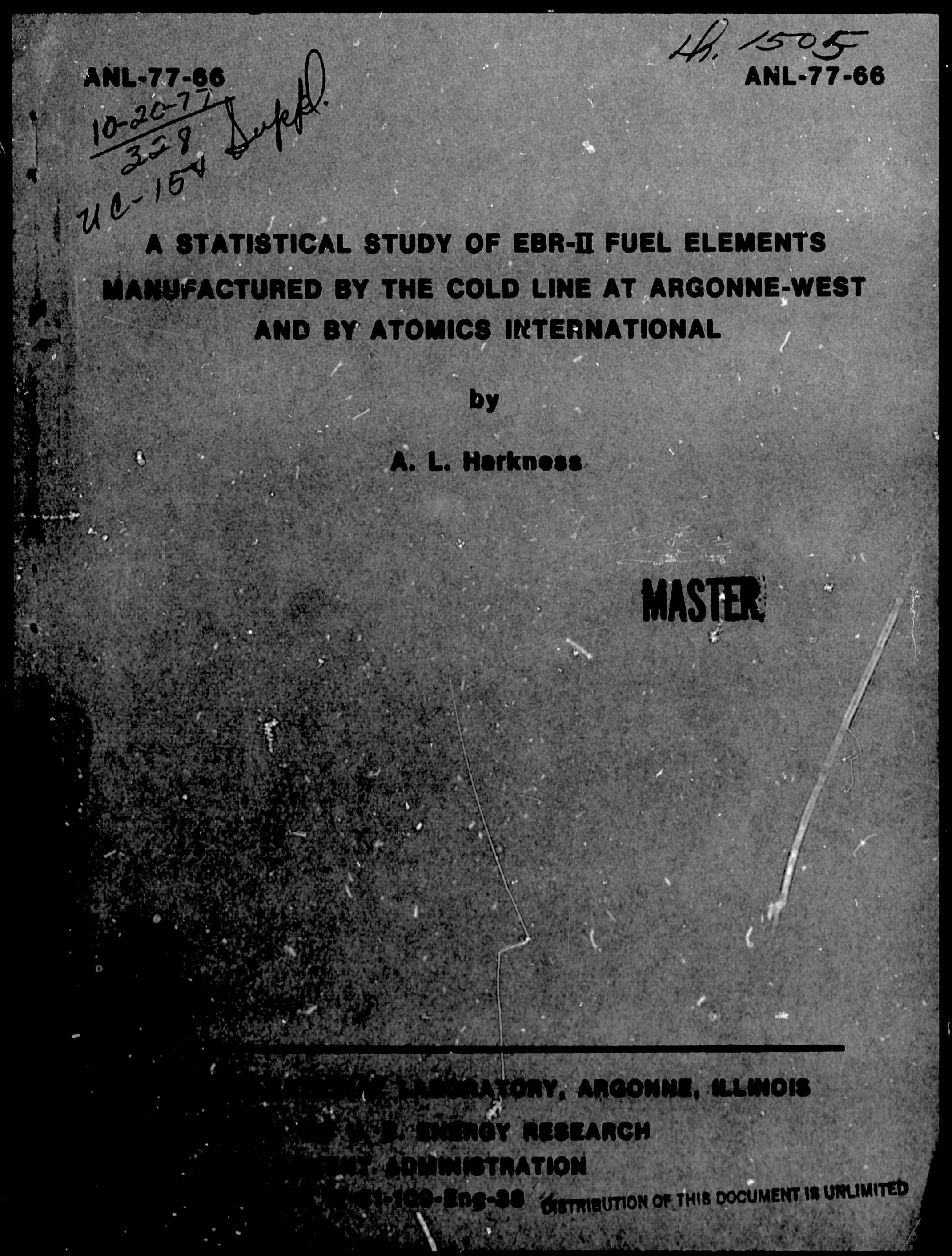




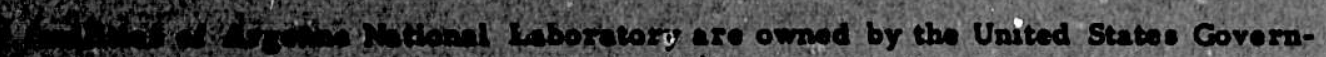

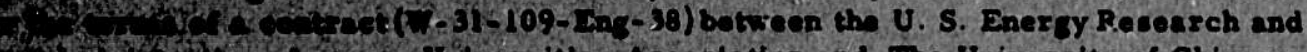

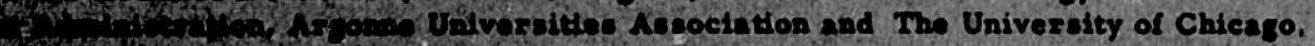

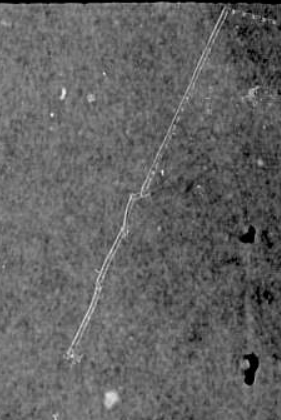
1)

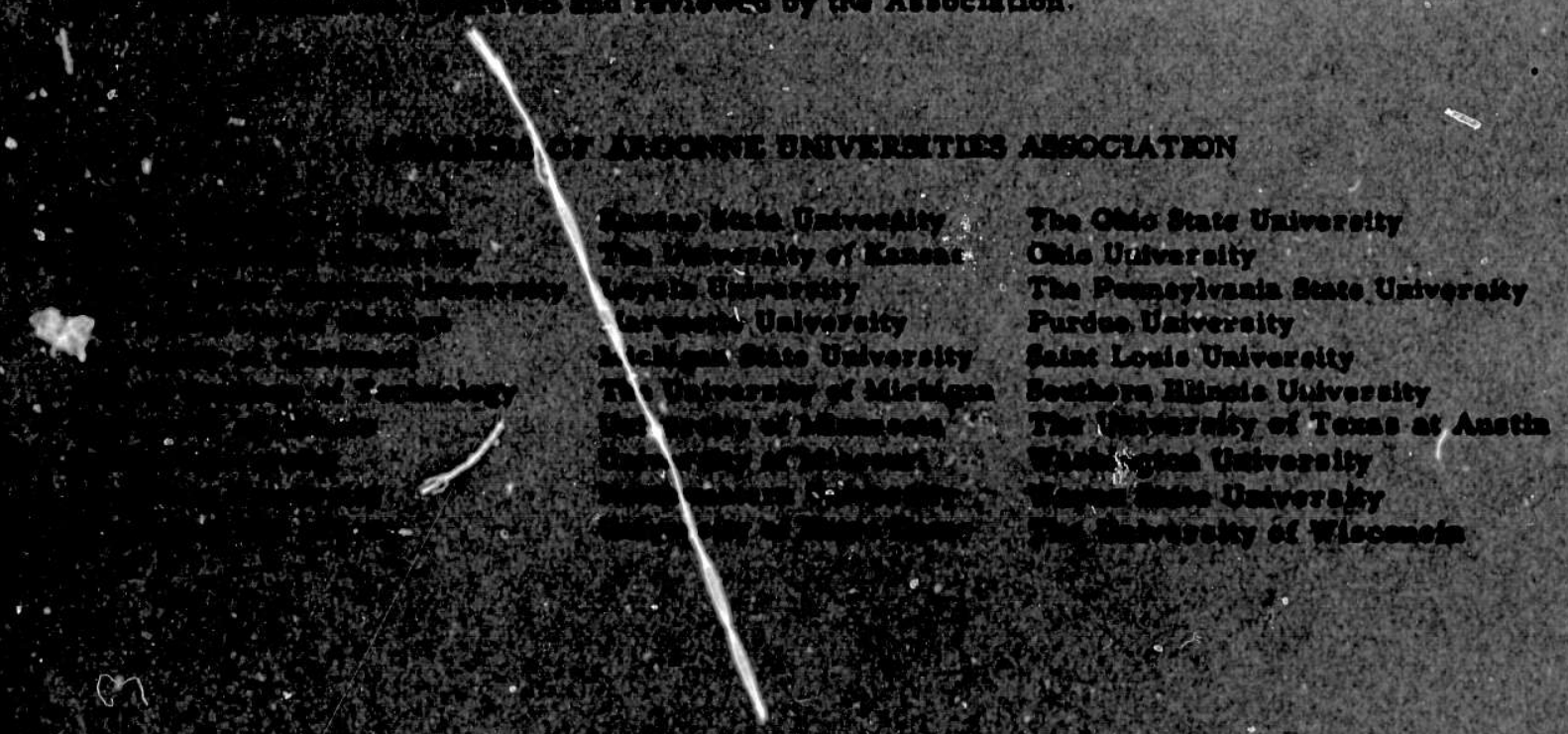

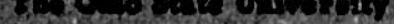

cio joustaly

Purdonithoilt

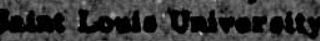

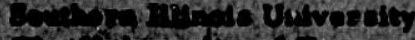

$-1 x^{2}$

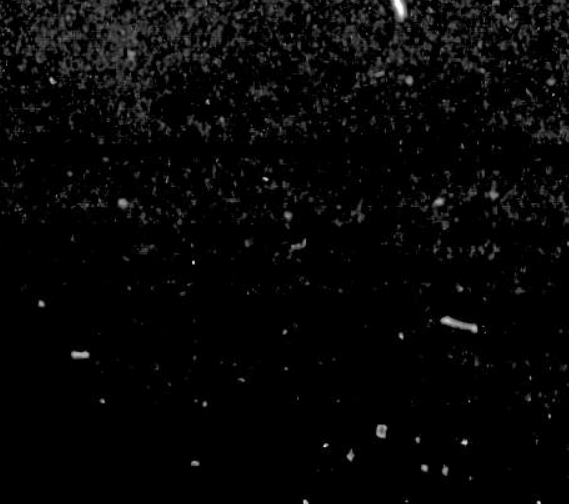

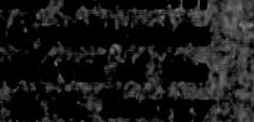

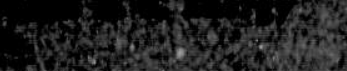

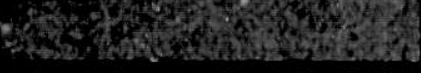

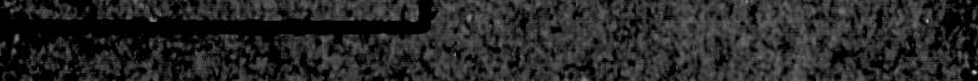
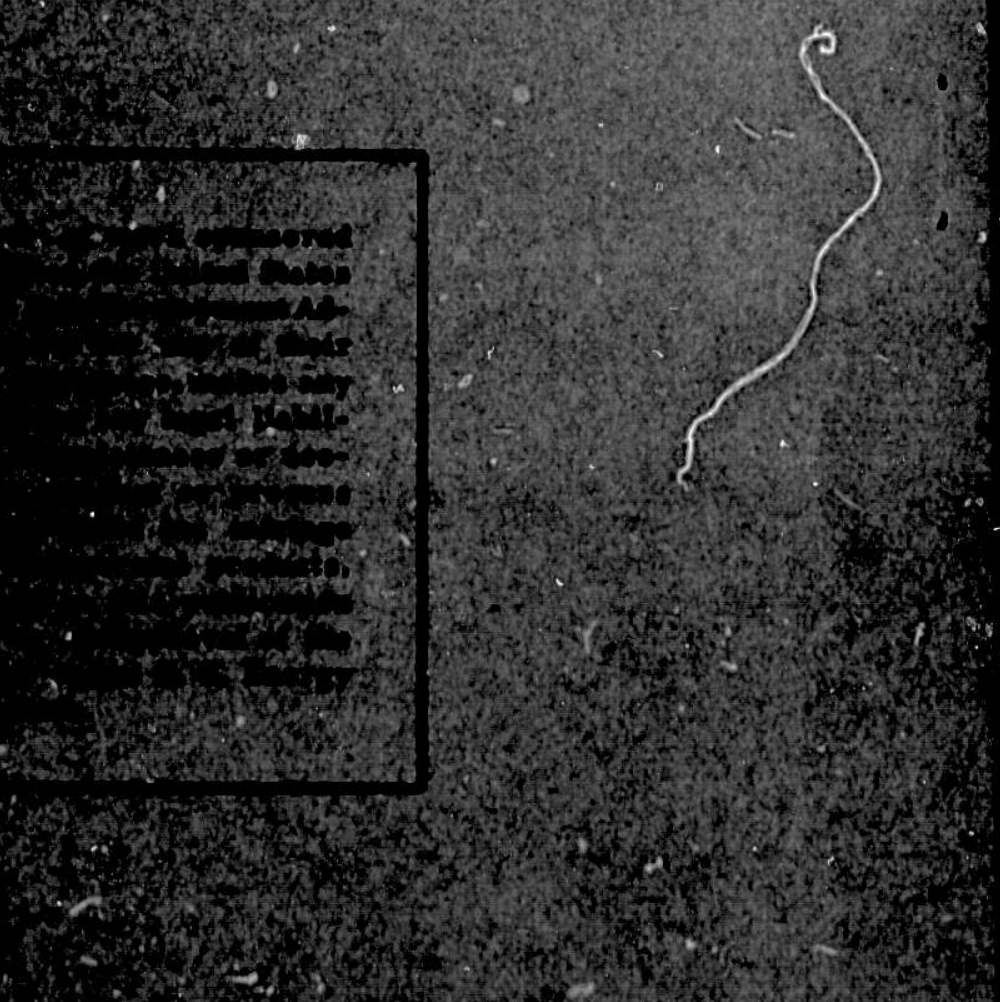

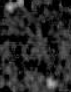

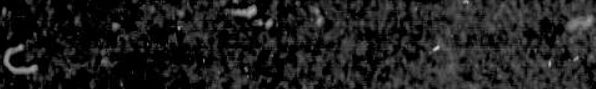

7 H 
Distribution Category:

Safeguards--Nuclear Materials Security (UC-15)

ANL-77-66

ARGONNE NATIONAL LABORATORY

9700 South Cass Avenue

Argonne, Illinols 60439

\section{A STATISTICAL STUDY OF EBR-II FUEL ELEMENTS \\ MANUFACTURED BY THE COLD LINE AT ARGONNE-WEST \\ AND BY ATOMICS INTERNATIONAL \\ by}

A. L. Harkness

Nondestructive Assay Section

Special Materials Division

September 1977

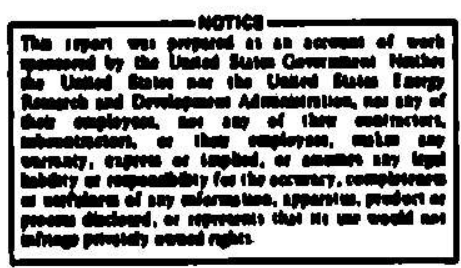





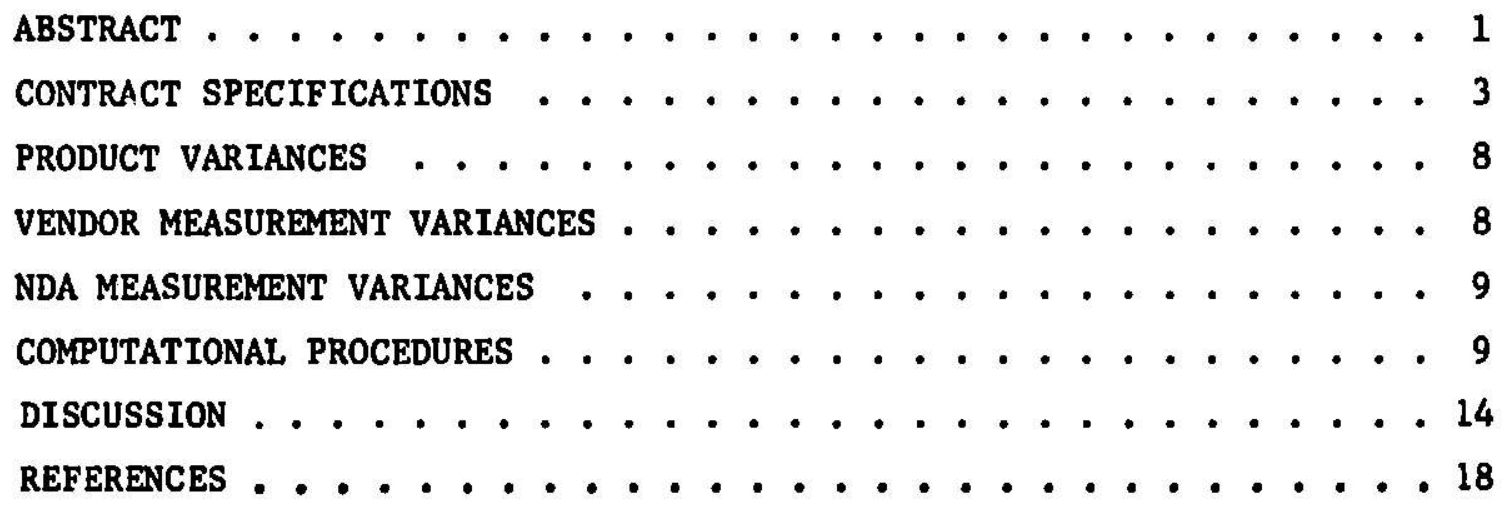


I. ANL-West FIrst Mark-II Job . . . . . . . . . . . 13

II. ANL-West Second Mark-II Job .............. 13

III. Atomics International Mark-II Job ............ 14

Iv. Aivi-West Mark-I Job ................. 14 


\begin{abstract}
A STATISTICAL STUDY OF EBR-II FUEL ELEMENTS MANUFACTURED BY THE COLD LINE AT ARGONNE-WEST AND BY ATOMICS INTERNATIONAL
\end{abstract}

by

A. L. Harkness

\begin{abstract}
Nine elements from each batch of fuel elements manufactured for the EBR-II reactor have been analyzed for U-235 content by NDA methods. These values, together with those of the manufacturer, are used to estimate the product variance and the variances of the two measuring methods. These variances are compared with the variances computed from the stipulations of the contract. A method is derived for resolving the several varlances Into their within-batch and between-batch components. Some of these variance components have also been estimated by Independent and more famillar conventional methods for comparison.
\end{abstract}


Fuel elements for the BBR-II reactor at Argonne-West have been prepared in several job lots by the Cold Line at Argonne-West and by Atomics International Company.

The manufacturing operation can be described brlefly as consisting of two operations. In the first, an alloy 18 made by melting uranium metal of the proper U-235 enrichment together with small amounts (5\% of the total) of the several fissium metals. Then, in an injection-casting operation, the alloy is remelted and cast into vycore-glass molds. The resulting pins are cut to length and the scrap 18 recycled to subsequent alloy runs. The following section discusses some of the pertinent specifications for the Mark-II fuel elements which have uranium of about $67 \%$ enrichment. The target uranium/fissium ratio and the total U-235 content of the Mark-I elements 18 the same as for the Mark-II elements. The enrichment of the Mark-I uranium is about 52\%, rather than 67\%, and therefore the Mark-I elements will contain about $29 \%$ more total material.

Each job lot consists of a large number of batches $(50<n<300)$, each of which produced elements varying in number from several to about 100 . The Vendor assigned a U-235 content to each element based on chemical and 1sotopic analyses of samples from each casting batch and the measured welght of each pin. Nine elements from each batch have been analysed by the Nendestruction Assay Section (NDA) of the Special Materials Division (SPM) using a gamma-counting method. ${ }^{2}$ As a result, there are two independently determined values for the U-235 content of a large number of elements for each job lot, all having the same target yalue. The varlance for each get of values has four componenta: a within-batch (subscripted $r$ for random) and a betweenbatch (subscripted $a$ for systemat1c) for both the product (P) and either the Vendor (V) or the NDA (N) measurement methods. That 1s, the total variances are 


$$
\operatorname{Var}\left(V_{T}\right)=\operatorname{Var}\left(V_{r s} P_{r s}\right)=\operatorname{Var}\left(V_{r}\right)+\operatorname{Var}\left(V_{s}\right)+\operatorname{Var}\left(P_{r}\right)+\operatorname{Var}\left(P_{s}\right)
$$

and

$$
\operatorname{Var}\left(\mathrm{N}_{T}\right)=\operatorname{Var}\left(\mathrm{N}_{\mathbf{r s}} \mathrm{P}_{\mathrm{rg}}\right)=\operatorname{Var}\left(\mathrm{N}_{\mathbf{r}}\right)+\operatorname{Var}\left(\mathrm{N}_{\mathbf{s}}\right)+\operatorname{Var}\left(\mathrm{P}_{\mathbf{r}}\right)+\operatorname{Var}\left(\mathrm{P}_{\mathbf{s}}\right)
$$

In the following, pertinent data from the contract specifications ${ }^{2}$ are used to compute the variance restrictions on the Vendor. Some of the sources of these variances are discussed. Finally, the methods used to compute the actual variances from the two sets of measurements are discussed with summary tables for each of the four job lots.

\section{CONTRACT SPECIFICATIONS}

The contract specifications ${ }^{2}$ read in part:

\subsection{TECHNICAL REQUIREMENTS}

3.2 Chemical Properties of Fuel Pin

3.2.1 The final composition of any sample from

\begin{tabular}{|c|c|}
\hline & $\begin{array}{c}\text { Analytically } \\
\text { Measured Composition }\end{array}$ \\
\hline Chnemical Element & Weight Percent \\
\hline Molybdenum & $2.44 \pm 0.17$ \\
\hline Ruthenium & $1.94 \pm 0.25$ \\
\hline Rhodium & $0.28 \pm 0.05$ \\
\hline Palladium & $0.19 \pm 0.04$ \\
\hline Ziroonium & $0.085 \pm 0.060$ \\
\hline Niobium & $0.015 \pm 0.012$ \\
\hline silioon & $0.050 \pm 0.027$ \\
\hline Uranium & $95.00 \pm 1.00$ \\
\hline Total Impum & 2550 ppm max. \\
\hline
\end{tabular}
any fuel pin shall be: 


$\begin{array}{lr}\text { Isotopic Uranium } & \text { Weight Percent } \\ 235_{U} & 66.72 \pm 0.50 \\ 234_{U}+{ }^{236} U+{ }^{238} U & 33.28 \pm 0.50 \\ 234 U+{ }^{236} U & <1.0\end{array}$

\subsection{Physical Properties}

3.3.2 The weight of the completed fuel pin shall be $51.7 \pm 1.0$ grams.

\subsection{QUALITY ASSURANCE AND CONTROL}

4.2.3 Analytical Procedures

The Seller shall establish precise chemical, mass spectrometric, or other analytical techniques that yield accuracy confidence intervals within the limits shown below:

Confidence Levels Required of Analysis Method of Fissium Alloy Fuel Pins

\% of Wt \% of Element Present

Chemical Element Analysis Method 95\% Conf. Int.

Total Uranium

$$
\pm 1.0
$$

Isotopic Uraniwn

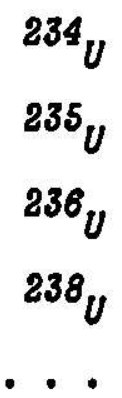

$$
\begin{aligned}
& \pm 10.0 \\
& \pm 1.0 \\
& \pm 10.0 \\
& \pm 1.0 \\
& . . .
\end{aligned}
$$

\footnotetext{
4.3.6.2 The following tolerances apply to the required asouracy on the physioal measuremente of completed fuel pins and elements.
} 


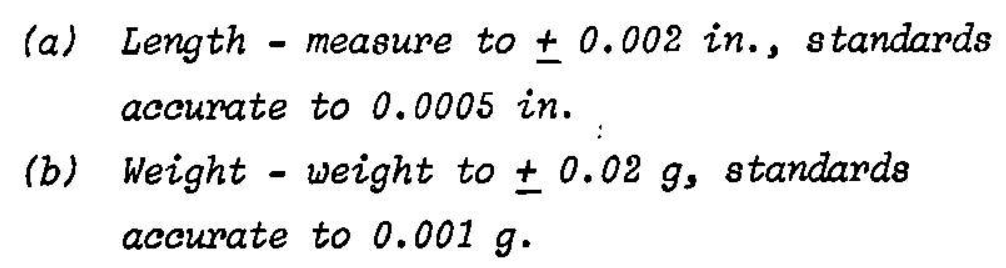

The values given in subsection 3.2 for the chemical and in subsection 3.3 for the physical properties of the fuel pins are sufficient for the computation of a specified total Vendor's variance, $\operatorname{Var}\left(V_{r s}{ }^{P} r s\right)$, for the U-235 content of the pins. Although it is not explicitly stated, the assumption is made that the limits refer to the $95 \%$ confidence level; that 1s, the limits are equal to $2 \sigma$. It is explicitly stated that the values are of the analytIcally measured composition.

Note that the first statement in subsection 3.2.1 is in conflict with what follows. The statement refers to the "composition" of the samples rather than the "measured composition" of the samples. Only the measured compositions can be known, and they will have a variance equal to the sum of the varlance of the product and the varlance of the measurement method.

The total U-235 content of a pin is

$$
Y=U \cdot I \cdot W
$$

where $U$ is the \% total uranium

I 18 the $\% \mathrm{U}-235$

$W$ is the pin weight in grams

$$
\begin{aligned}
\operatorname{Var}\left(V_{r s}{ }_{r s}\right) & =\left(\frac{\delta Y}{\delta U} \cdot \sigma_{U}\right)^{2}+\left(\frac{\delta Y}{\delta I} \cdot \sigma_{I}\right)^{2}+\left(\frac{\delta Y}{\delta W} \cdot \sigma_{W}\right)^{2} \\
& =\left(I \cdot W \cdot \sigma_{U}\right)^{2}+\left(U \cdot W \cdot \sigma_{I}\right)^{2}+\left(U \cdot I \cdot \sigma_{W}\right)^{2}
\end{aligned}
$$




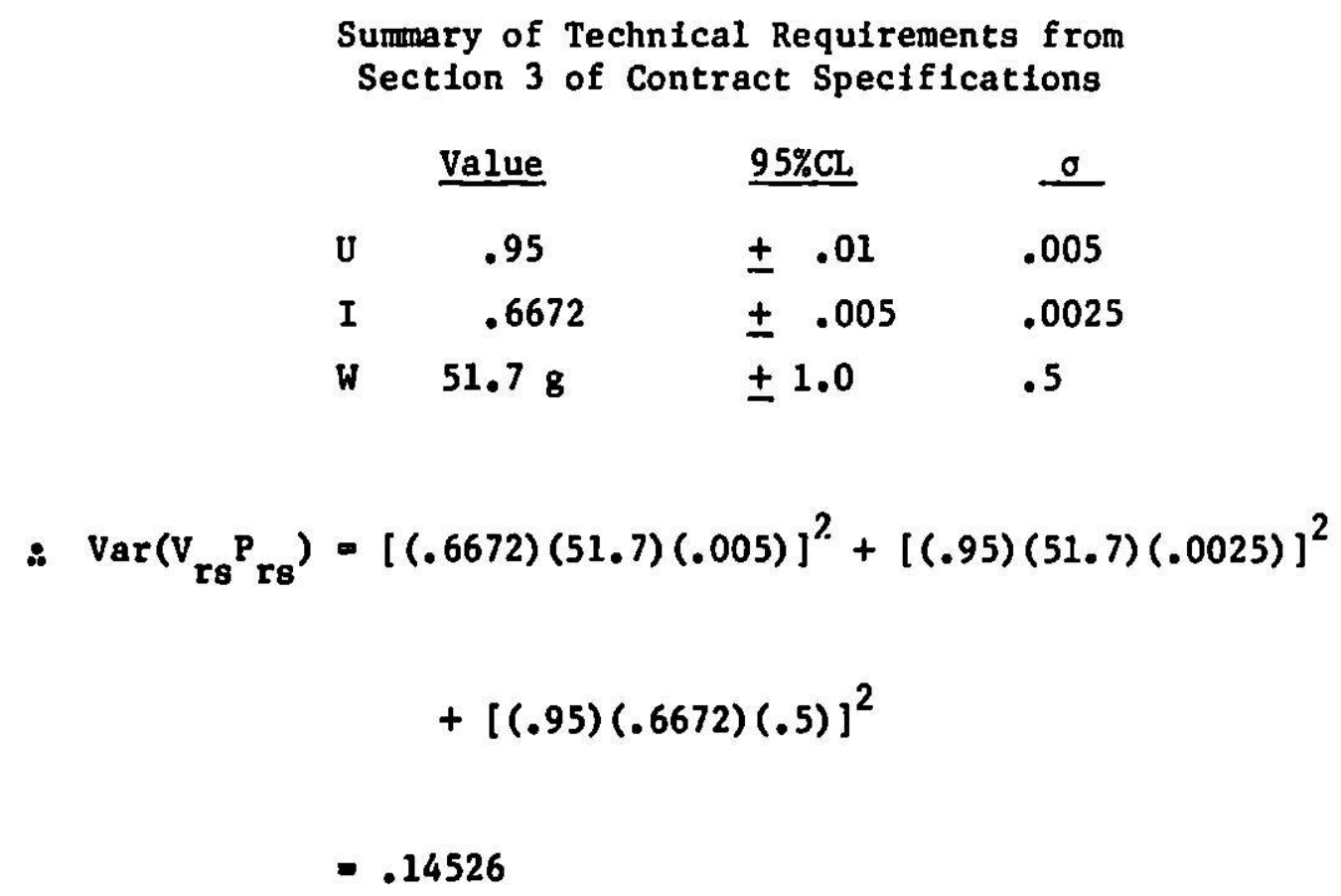

This value, computed from the contract specifications, can be compared to the $\operatorname{Var}\left(\mathrm{V}_{\mathrm{rs}_{\mathrm{B}}{ }_{\mathrm{r}}}\right)$ actually achieved for the four job lots of elements. These values are 11 sted in the first column of the first row of Tables I-IV, below, which summarize the analytical results.

The values given In subsection 4 refer to the precision of the Vendor's measurement methods. It 18 explicitly stated that the values given refer to the $95 \%$ confidence level; they are therefore equal to 20 . The values given for total uranium and the several lsotopes are expressed as percentages of the amount present. These are converted to absolute amounts in the followIng computations. It 18 specifled that welghings be made to .02 grams. The weights then belong to a uniform, or rectangular, distribution. The standard deviation, $\sigma$, of such a distribution is the range divided by $\sqrt{12}$. Therefore

$$
\sigma_{W}=(.02) / \sqrt{12}=.00577 \text { grams. }
$$


Summary of Quality Control Requirements from Section 4.0 of Contract Specifications

95\% CL

\begin{tabular}{|c|c|c|c|}
\hline Value & $\%$ & Absolute & o \\
\hline .95 & 1.0 & .0095 & .00475 \\
\hline .6672 & 1.0 & .00667 & .0033 \\
\hline $51 . .7$ & - & - & .00577 \\
\hline
\end{tabular}

These values are substituted into Eq. 4. Because the varlances involved $\left(\sigma_{W}{ }^{2}, \sigma_{U}{ }^{2}\right.$, and $\left.\sigma_{I}{ }^{2}\right)$ are those of the measuring method only, with no contribution from the product, we have:

$$
\operatorname{Var}\left(\mathrm{V}_{\mathrm{rB}}\right)=.05361
$$

Th1s 18 the net 1 imiting Vendor's measurement varlance as specifled by the contract and can be compared with the fifth item in the first column of Tables I-IV below.

An Implied, allowed product variance can be computed as

$$
\begin{aligned}
\operatorname{Var}\left(P_{r 8}\right) & =\operatorname{Var}\left(P_{r 8} V_{r 8}\right)-\operatorname{Var}\left(V_{r 8}\right) \\
& =.14526-.05361 \\
& =.09165
\end{aligned}
$$

or

$$
\sigma_{\mathrm{P}}=\sqrt{\operatorname{Var}\left(\mathrm{P}_{\mathrm{rB}}\right)}=.303
$$


95\% of the elements from a given job lot must have a U-235 content within .606 grams $(2 \sigma)$ of their average.

PRODUCT VARIANCES

About $10 \mathrm{~kg}$ of uranium of the proper enrichment and a sufficient quantity of the several fissium metals are melted together to produce an alloy which 1s $95 \%$ uranium. The first alloy batches are made with virgin metal, but later batches may be partially or completely made up of scrap from previous infection-casting batches, and a small amount of added molybdenum calculated to replace that lost during the previous alloying process. About $95 \%$ of the charge becomes usable alloy, and about $5 \%$ becomes an oxidized scrap called dross. During this process the fissium metals, notably molybdenum, preferentially enter the dross, leaving the alloy slightly rich in uranium. This amount will vary in a random manner from run to run, and is probably the major component of the between-batch product variance, $\operatorname{Var}\left(P_{8}\right)$. Another component would be the random error in adjusting the uranfum- and f1381umcharge amounts to equal the target value. This component would likely be greater for those runs containing a large amount of recycle materlal, because the uranium and fissium contents are deterwined frow a chemical analysis rather than from the more accurate method of welghing the pure elemental metals.

In a second process, the alloy 18 melted in a vacuum furnace and injected Into vycore-glass tubing. When cool the glass is removed, and the pins are cut to length and weighed. There is some separation of the alloy components during this process; that 18, the uranium/fissium ratio varies over the pin length and, undoubtedly, from pin to pin. This, together with the randomnass of the pin weights, 18 the major component of the within-batch product varlance, $\operatorname{Var}\left(\boldsymbol{P}_{\mathbf{r}}\right)$.

\section{VENDOR MEASURBYBNT VARIANCES}

The main cources of the between-batch Vendor-measurement variance, $\operatorname{Var}\left(V_{8}\right)$. are the analytical and aapling errore in determining the total uranium and the U-235 content of the casting material. The within-batch Vendor-mea- 
surement variance, $\operatorname{Var}\left(\mathrm{V}_{\mathbf{r}}\right)$, s pactly because the same identical analytical values are applied to all pins in a batch when it is known that the melt is not perfectly uniform, and partly because of the random errors in weighing the pins. Note that $\operatorname{Var}\left(\mathrm{P}_{\mathbf{r}}\right)$ results from the differences between the true values of the U-235 content of the individual pins and the average value of this quantity for all pins, while $\operatorname{Var}\left(v_{\mathbf{r}}\right)$ results from the differences between these true values and the assigned values which are computed assuming that the alloy is of uniform composition.

\section{NDA MEASUREMENT VARIANCES}

In the NDA gamma-counting method of analysis, nine elements from each of two batches, together with five standard elements, are placed on the scanning table. The five standards are scanned twice on each side, and the ganma counts collected are used to construct a callbration curve. Each sample element Is scanned once on each side, and the gamma counts collected are converted to grams of U-235 using the calfbration curve. The between-batch NDA variance, $\operatorname{Var}\left(N_{8}\right)$, results from the errors in constructing the calibration curves which will vary in a random manner from run to run. The withinbatch variance, $\operatorname{Var}\left(N_{r}\right)$, results primarily from the cointing statistics on the measured elements.

\section{COMPUTATIONAL PROCEDURES}

Grubbe ${ }^{3}$ suggested that total product and measurement variances can be estimated from sets of measurements by two or more methods on each of a number of similar, but not identical products. This results from the fact that the expected value of the covarlance between two measurement sets is the total product variance $\left(\operatorname{Var}\left(\mathrm{P}_{\mathrm{rg}}\right)\right)$. This 18 demonstrated as follows:

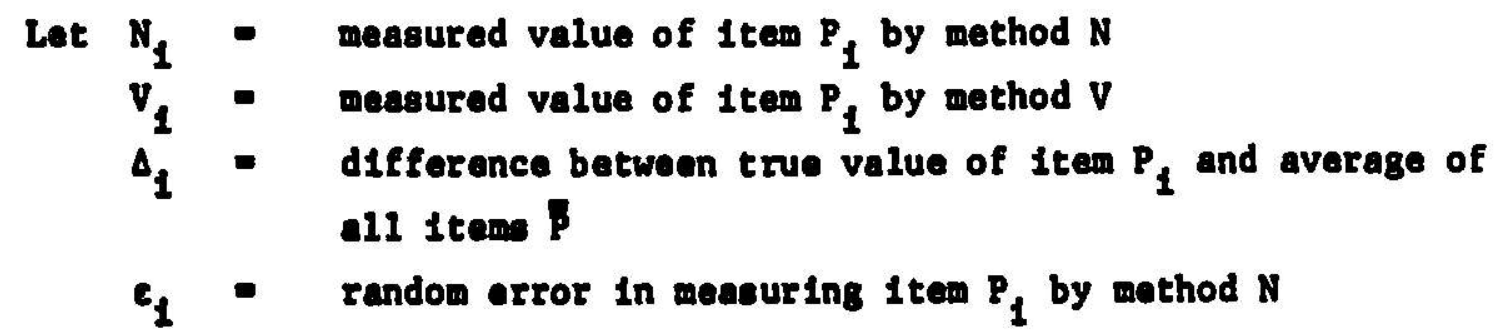




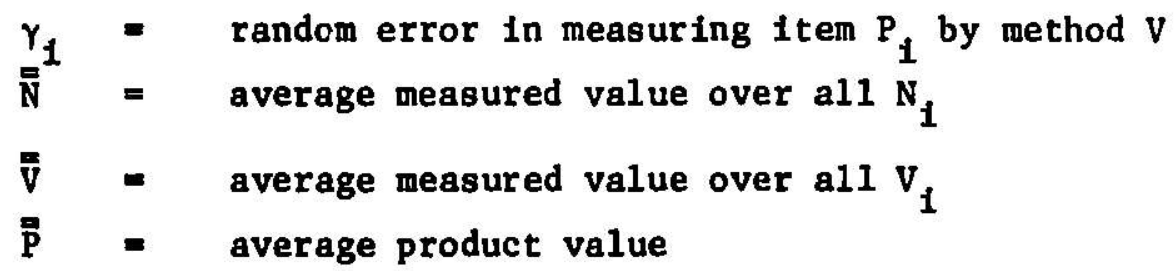

The expected value of both $\overline{\bar{N}}$ and $\overline{\bar{V}}$ is $\overline{\bar{P}}$, plus, perhaps, a bias. If there is a blas in $\bar{N}$ or $\bar{V}$, it will also occur in each of the Individual measurements $\mathrm{N}_{1}$ or $\mathrm{V}_{1}$ and 80 will be subtracted out in the following equations. The covarfance between $\mathrm{N}_{1}$ and $\mathrm{v}_{1}$ is

$$
\begin{aligned}
\operatorname{Covar}(\mathrm{NV})= & \Sigma\left(\mathrm{N}_{1}-\overline{\mathrm{N}}\right)\left(\mathrm{V}_{1}-\overline{\bar{V}}\right) /(\mathrm{n}-1) \\
& =\Sigma\left(\overline{\mathrm{P}}+\Delta_{1}+\varepsilon_{1}-\overline{\mathrm{N}}\right)\left(\overline{\mathrm{P}}+\Delta_{1}+\gamma_{1}-\overline{\mathrm{V}}\right) /(\mathrm{n}-1) \\
& =\Sigma\left(\Delta_{1}^{2}+\Delta_{1}\left(\varepsilon_{1}+\gamma_{1}\right)+\varepsilon_{1} \gamma_{1}\right) /(\mathrm{n}-1) \\
& \left(\Sigma \Delta_{1}{ }^{2}+\Sigma \Delta_{1}\left(\varepsilon_{1}+\gamma_{1}\right)+\varepsilon \varepsilon_{1} \gamma_{1}\right) /(n-1)
\end{aligned}
$$

The expected vaiues of the second and third sums in the numerator are zero. We then have:

$$
\begin{aligned}
\operatorname{Covar}(\mathrm{NV}) & =\quad \sum \Delta_{1}{ }^{2 /(n-1)} \\
& =\operatorname{Var}\left(\mathrm{P}_{\mathrm{r8}}\right)
\end{aligned}
$$

Since the varlance computed from the two sets of measurements are

$$
\operatorname{Var}\left(N_{T}\right)-\varepsilon\left(N_{1}-N\right)^{2} /(n-1)=\operatorname{Var}\left(N_{r 8}\right)+\operatorname{Var}\left(P_{r 8}\right)
$$

and

$$
\operatorname{Var}\left(V_{T}\right)=\Sigma\left(V_{1}-\bar{V}\right)^{2} /(n-1)-\operatorname{Var}\left(V_{r 8}\right)+\operatorname{Var}\left(P_{r g}\right)
$$


the variances of the two methods are

$$
\begin{aligned}
& \operatorname{Var}\left(\mathrm{N}_{\mathrm{rs}}\right)=\operatorname{Var}\left(\mathrm{N}_{\mathrm{T}}\right)-\operatorname{Covar}(\mathrm{NV}) \\
& \operatorname{Var}\left(\mathrm{V}_{\mathrm{rs}}\right)=\operatorname{Var}\left(\mathrm{V}_{\mathrm{T}}\right)-\operatorname{Covar}(\mathrm{NV})
\end{aligned}
$$

It 18 also possible to compute $\operatorname{Var}\left(\mathrm{N}_{\mathrm{rs}} \mathrm{V}_{\mathrm{rs}}\right)$ from the paired set of data

$$
\operatorname{Var}\left(N_{r s} V_{r s}\right)=\sum\left[\left(N_{1}-V_{1}\right)-(\overline{\overline{N-V}})\right]^{2} /(n-1)
$$

This is the variance which is used in the familiar paired-difference test to estimate the significance of the difference between the average of two sets of measurements. It also provides a slightly different computational approach to the resolution of the three composite variances $\operatorname{Var}\left(\mathrm{P}_{\mathrm{rs}}\right), \operatorname{Var}\left(\mathrm{N}_{\mathrm{rs}}\right)$, and $\operatorname{Var}\left(\mathrm{v}_{\mathbf{r 8}}\right)$ :

$$
\operatorname{Var}\left(\mathrm{N}_{\mathrm{T}}\right)+\operatorname{Var}\left(\mathrm{V}_{\mathrm{T}}\right)-\operatorname{Var}\left(\mathrm{N}_{\mathrm{rs}} \mathrm{V}_{\mathrm{rs}}\right)=2 \operatorname{Var}\left(\mathrm{P}_{\mathrm{rs}}\right)
$$

The measurement variances are then computed as in Eqs. 9 and 10 above, remembering the identity

$$
\operatorname{Var}\left(P_{r 8}\right)=\operatorname{Covar}\left(\mathrm{N}_{r 8} \mathrm{~V}_{r 8}\right)
$$

It can be shown that the two computational approaches are mathematically 1dentical. The $81 x$ variances $\left[\left(\operatorname{Var}\left(\mathrm{V}_{r 8}{ }_{r 8}{ }_{r 8}\right), \operatorname{Var}\left(\mathrm{N}_{r s}{ }_{r 8}\right), \operatorname{Var}\left(\mathrm{N}_{r 8} \mathrm{~V}_{r 8}\right), \operatorname{Var}\left(\mathrm{P}_{r 8}\right)\right.\right.$ - $\operatorname{Covar}\left(\mathrm{N}_{\mathrm{rg}} \mathrm{V}_{\mathrm{rg}}\right), \operatorname{Ver}\left(\mathrm{V}_{\mathrm{rg}}\right)$ and $\left.\operatorname{Var}\left(\mathrm{N}_{\mathrm{rg}}\right)\right]$, computed from the date of each of the four fob lots, are listed in the first column of corresponding Tables I-IV below.

If there were no between-batch variances, then the expected results would be the same as if the nine elements which are measured at the same time were drawn at random from the total population with no regard to their batch Identity. In this case the expected variances of the average of nine U-235 contents would be $1 / 9$ of the variances of unit weight which have been 
discussed above. The process described above was repeated, using as data the $n$ batch average values, where $n$ is the number of batches. The results are listed in the second column of the table. A cursory examination shows that these varlances are considerably larger than 1/9 of the corresponding varfances of unft weight. This indicates that there is an error component which is the same for each element of a batch, and therefore also for the batch average. These two components can be separated by the solution of a pair of equations: the first indicating that the variances of unit weight are the sums of the between-batch and the within-batch variances, and the second Indicating that the batch average varlances are the sums of the between-batch and $1 / 9$ of the within-batch variances. In the following, the general variable $X$ is used in place of $P, V$, or $N$. A single bar is used $(\bar{X})$ to Indicate a batch average, whereas a double bar $(\overline{\bar{X}})$ has been used to Indicate the average over the total fob lot.

$$
\begin{aligned}
& \operatorname{Var}\left(\mathrm{X}_{\mathbf{r s}}\right)=\operatorname{Var}\left(\mathrm{X}_{\mathrm{s}}\right)+\operatorname{Var}\left(\mathrm{X}_{\mathbf{r}}\right) \\
& \operatorname{Var}\left(\overline{\mathrm{X}}_{\mathbf{r s}}\right)=\operatorname{Var}\left(\mathrm{X}_{\mathrm{s}}\right)+\operatorname{Var}\left(\mathrm{X}_{\mathbf{r}}\right) / 9
\end{aligned}
$$

or

$$
\begin{aligned}
& \operatorname{Var}\left(\mathrm{X}_{\mathrm{r}}\right)=(9 / 8)\left[\operatorname{Var}\left(\mathrm{X}_{\mathrm{rs}}\right)-\operatorname{Var}\left(\overline{\mathrm{X}}_{\mathrm{rg}}\right)\right] \\
& \operatorname{Var}\left(\mathrm{X}_{8}\right)=\left[9 \operatorname{Var}\left(\overline{\mathrm{X}}_{\mathrm{r} 8}\right)-\operatorname{Var}\left(\mathrm{X}_{\mathrm{r} 8}\right)\right] / 8
\end{aligned}
$$

The resulting values for the systematic or between-batch variances, $\operatorname{Var}\left(\mathrm{x}_{8}\right)$, are given in column 3 , and the within-batch variances in column 4 of the tables.

A second method of estimating the within-batch variances ts to compute the varlances for each batch separately to obtain $n$ estimates based on 8 degrees of freedom. The average of these $n$ values are listed in column 5 of the tables for comparison with column 4 .

A second method was also used to estimate the total NDA variance $\operatorname{Var}\left(\mathbb{N}_{\text {rs }}\right)$. 
The table of the gamma-ray scanning apparatus has positions for 24 elements; 18 of these were used for the samples being measured, and 5 for the standards. The remaining position was used to obtain replicate analyses on one element. Ine element used had been prepared as a standard with a chemical and isotopic content equal to the target value for Mark-II elements. The variance computed from 220 independent measurements of this element is .0431. This can be compared with the four other estimates which are 11sted as the last Item of the first column of the four tables. The weighted average of these four values is .0435 .

TABLE I. ANL-West First Mark-II Job

$\begin{array}{lccccc} & \operatorname{Var}\left(\mathrm{X}_{\mathrm{rs}}\right) & \operatorname{Var}\left(\overline{\mathrm{X}}_{\mathrm{rs}}\right) & \operatorname{Var}\left(\mathrm{X}_{\mathrm{s}}\right) & \operatorname{Var}\left(\mathrm{X}_{\mathbf{r}}\right) & \operatorname{Var}\left(\mathrm{X}_{\mathbf{r}}\right) \\ & & & & \\ \operatorname{Var}(\mathrm{VP}) & .024394 & .015027 & .013856 & .010539 & .010605 \\ \operatorname{Var}(\mathrm{NP}) & .053986 & .011914 & .006655 & .047331 & .047363 \\ \operatorname{Var}(\mathrm{NV}) & .061629 & .019653 & .014406 & .047222 & .047291 \\ \operatorname{Var}(\mathrm{P}) & .008376 & .003644 & .003052 & .005324 & .005338 \\ \operatorname{Var}(\mathrm{V}) & .016018 & .011383 & .010803 & .005215 & .005267 \\ \operatorname{Var}(\mathrm{N}) & .045610 & .008270 & .003603 & .042007 & .042025\end{array}$

Number of Batches 209

Average U-235 Content

Vendor

32.978

NDA

$32.90 \mathrm{~g}$

TABLE II. ANL-West Second Mark-II Job

$$
\operatorname{Var}\left(\mathrm{x}_{\mathrm{rs}}\right) \operatorname{Var}\left(\overline{\mathrm{x}}_{\mathrm{r} \boldsymbol{s}}\right) \operatorname{Var}\left(\mathrm{x}_{\mathrm{s}}\right) \quad \operatorname{Var}\left(\mathrm{x}_{\mathbf{r}}\right) \quad \operatorname{Var}\left(\mathrm{x}_{\mathbf{r}}\right)
$$

$\begin{array}{llllll}\operatorname{Var}(V P) & .020414 & .011940 & .010881 & .009533 & .009658 \\ \operatorname{Var}(\text { NP) } & .046790 & .009497 & .004835 & .041955 & .042010 \\ \operatorname{Var}(\text { NV) } & .051900 & .013981 & .009241 & .042659 & .042765 \\ \operatorname{Var}(P) & .007652 & .003728 & .003238 & .004415 & .004452 \\ \operatorname{Var}(V) & .012762 & .008212 & .007643 & .005119 & .005206 \\ \operatorname{Var}(N) & .039138 & .005769 & .001598 & .037540 & .037558\end{array}$

Number of Batches 87

Average U-235 Content

Vendor 32.668

NDA 
TABLE III. Atomics International Mark-II Job

$\begin{array}{lccccc} & \operatorname{Var}\left(\mathrm{x}_{\mathrm{rs}}\right) & \operatorname{Var}\left(\overline{\mathrm{x}}_{\mathrm{rs}}\right) & \operatorname{Var}\left(\mathrm{x}_{\mathrm{s}}\right) & \operatorname{Var}\left(\mathrm{x}_{\mathbf{r}}\right) & \operatorname{Var}\left(\mathrm{x}_{\mathrm{r}}\right) \\ & & & & & \\ \operatorname{Var}(\mathrm{VP}) & .028961 & .017557 & .016131 & .012829 & .012894 \\ \operatorname{Var}(\mathrm{NP}) & .054060 & .014484 & .009537 & .044523 & .044561 \\ \operatorname{Var}(\mathrm{NV}) & .059510 & .019302 & .014276 & .045234 & .045291 \\ \operatorname{Var}(\mathrm{P}) & .011755 & .006369 & .005696 & .006059 & .006082 \\ \operatorname{Var}(\mathrm{V}) & .017205 & .011180 & .010435 & .006770 & .006812 \\ \operatorname{Var}(\mathrm{N}) & .042305 & .008115 & .003841 & .038464 & .038479\end{array}$

Number of Batches 232

Average U-235 Content

$\begin{array}{ll}\text { Vendor } & 32.67 \mathrm{~g} \\ \text { NDA } & 32.80 \mathrm{~g}\end{array}$

TABLE IV. ANL-West Mark-I Job

$\operatorname{Var}\left(\mathrm{x}_{\mathrm{r} B}\right) \operatorname{Var}\left(\overline{\mathrm{x}}_{\mathrm{rs}}\right) \operatorname{Var}\left(\mathrm{x}_{\mathrm{s}}\right) \quad \operatorname{Var}\left(\mathrm{x}_{\mathrm{r}}\right) \quad \operatorname{Var}\left(\mathrm{x}_{\mathbf{r}}\right)$

$\begin{array}{lrrrrr}\operatorname{Var}(\text { VP) } & .028865 & .025412 & .024981 & .003884 & .004374 \\ \operatorname{Var}(\mathrm{NP}) & .047742 & .008095 & .003139 & .044602 & .044664 \\ \operatorname{Var}(\mathrm{NV}) & .076572 & .036814 & .031844 & .044728 & .045352 \\ \operatorname{Var}(\mathrm{P}) & .000017 & -.001653 & -.001862 & .001879 & .001843 \\ \operatorname{Var}(\mathrm{V}) & .028848 & .027065 & .026842 & .002005 & .002531 \\ \operatorname{Var}(\mathrm{N}) & .047725 & .009748 & .005001 & .042723 & .042821\end{array}$

Number of Batches 51

Average U-235 Content

Vendor

31.688

NDA

31.698

\section{DISCUSSION}

The treatment described above might be considered an empirical test of the Grubbs method. Very Ifttle theoretical atudy of the method has been made since Grubbs suggested it in 1948. A number of people have discussed the fact that negative values of the measurement varlance can occur when using this method, but that the probability of this happening decreases 
as the product varlance decreases and the number of degrees of freedom Increases. 4,5

Winslow ${ }^{6}$ has recently shown that the measurement variance estimated from a set of measurements on a number of different products having a known product varlance follows a noncentral chi square distribution instead of the chl square distribution assoclated with varfances estimated in the usual way. The shape of the noncentral chi square distribution curve is similar to that of the central chi square distribution curve for the same number of degrees of freeriom. Instead of terminating at zero, the noncentral curve is shifted into the negative region by an amount dependent on the product variance. As the number of degrees of freedom increases, both curves become flatter and extend further in the positive direction while the lower terminating points remain fixed. When the number of degrees of freedom is large, the relative difference between the means of the two curves decreases to an insignificant value, and the fraction of the noncentral curve in the negative region becomes negligible. The Grubbs method cannot be applied to all sets of data. In order for the data to be used with some degree of conf1dence, it must have a large number of degrees of freedom, and the variances must be relatively small. The data used here for the EBR-II fuel elements fit these criteria.

The NDA measurement varlance, $\operatorname{Var}\left(\mathrm{N}_{\mathrm{rs}}\right)$, estimated from 220 replicate measurements of a single element (.0431) agrees very well with the values computed using the Grubbs method. Th1s, together with the fact that the $\mathrm{NDA}^{\prime} \mathrm{s}$ and the Vendor's data enter the computations in a symetrical way, suggests that the variances computed for the Vendor's measurement are also good approximations of the true values.

The variance estimated for the AI product (.011755) Is significantly different from the variance estimated for elther of the Cold LIne Mark-II job lots (.008376 and .007652). Note that the term "significantly different" means only tha! it is very probably real and not due to random variatIons. It does not necessarily mean that the difference is very large or serious. The limit of error [LE $-2 \star \sqrt{\operatorname{Var}(P)}]$, In grams, for the three job lots (AI, Cold Line (1), and Cold Line (2)) are .218, .183, and .175, respec- 
tively. This means that the grams of $\mathrm{U}-235$ in $95 \%$ of the elements in the job lot are expected to be within these LEs of the average U-235 content of all elements in the lot. All three of these values are well within the limit of .606 grams which was computed from the contract specifications. The Vendor's measurement variances $(.0160, .0128$, and .0288 for ANL-W, and .0172 for AI) are also within the 1 imit of .0536 which was computed from the contract specifications.

There are some anomalies in the variances est imated for Mark-1 elements manufactured at the ANLW Cold Line, Table IV above. The total product variance is estimated to be very close to zero. This variance is computed as the covariance between the two sets of measurements (see Eq. 5 above), In order for the computed value to be correct, it is necessary that, as the attribute value (In this case the U-235 content) changes from item to 1 tem, the measured values by both methods will, on the average, change in the same direction by the same amount. If either or both measurements are not correlated to the attribute content of the elements, the expected result is a zero covarlance, as is observed. There 1s, of course, a finite probability that a result such as this could occur even when all systens are operating properly, but, with the large number of degrees of freedom that we have, this probability is quite small. It' is more likely that this result is due to something Inherent in one or both of the measuring methods. The MarkI elements are made of about 52\%-enriched uranium, and the Mark-II elements are made of about 67\%-enriched uranium. As they both have about the same target U-235 content, the Mark-I elements must contain about $67 / 52=1.29$ times as much total uranium as the Mark-II elemente. The main constituents of the within-batch product variance are the randon variation of the uranium/fiasium ratio and the pin weights. These are expected to be about the same for the Mark-I and the Mark-II pins. As the Mark-I pins are more dilute In U-235, the variance in the U-235 content is expected to be smaller (by about a factor of .6) than that in the Mark-II pins, but not by the factor of about .0025 which is computed. The NDA gamma-counting method will ineasure the total U-235 content of thin samples. As this thickness increases, self-absorption of the gamma rays becomes a more prominent feature. At some limiting thickness, the method becomes Insensitive to increased thickness, and the measuring device becomes essentially an enrichment meter. This ef- 
fect would be more pronounced with the Mark-I elements which have cores of greater diameter.

The Vendor's variance of the batch averages for the Mark-I job lot is very large (.0254). This is about 0.88 of the Vendor's variance of unit welght (.0288). For the three Mark-II job lots, this ratio falls in the range 0.58 to 0.61 . Something about the Vendor's reported values for the Mark-I elements is definitely different. The data has been carefully checked for errors and outliers to explain the difference, but none has been found. If the data is taken as correct, the conclusion is drawn that there Is a much larger batch-to-batch variance for the Mark-I elements than for the Mark-II elements. Because the total Vendor varlance $\operatorname{Var}\left(\mathrm{V}_{\left.\mathrm{rs}{ }^{\mathrm{P}}{ }_{\mathrm{rs}}\right) \text { for }}\right.$ all four job lots is about the same, the within-batch variance for the MarkI elements must be very small. It is difficult to speculate on the cause of this anomaly in the Vendor's variances, but quite feasibly the cause might also explain the extremely low computed value for the product variance.

The NDA measurement varlances computed for the four job lots (.0456, $.0391, .0423$, and .0477) are all well within the 11mit computed from the contract specifications (.0536) as being requi:red of the Vendor. Although these varlances are, as expected, greater than those for destructive measurement techniques, they are sufficlently small that the method will Jetect discrepancies between the product pins and the specifications with a high degree of certainty. It has also been demonstrated that the NDA gammacounting method is sufficlently stable and precise to provide the second set of data required for the Grubbs analysis technique. 
REFERENCES

1. Brandenburg, R. W.; Dudey, R. L。; Perry, R. B.; Beyer, N. S.: Proceedings of the D1gital Equipment Computer Users Society, San Diego, Cal1fornia, November, 1974.

2. Specification No. E0288-0002-SF-02, "EBR-II Driver Fue1 Pins and Elements, Mark II," prep. C. M. Walter, EBR, Idaho Falls, May 7, 1973.

3. Grubbs, F. E.: J. Amer. Statist. Assn., 43, 243-74, 1948.

4. Thompson, W. A.: J. Amer. Statist. Assn., 58, 474-0, 1963.

5. Jaech, J. L.: Nuclear Materlals Management Journal, Vo1. IV, No. IV, Winter, 1975-76.

6. Winslow, G. H.: Nuclear Materials Management Journal, Vo1. V, No. IV, Winter, 1976-77. 
Distribution for ANL-77-66

Internal:

J. A. Kyger

H. O. Monson

A. Amorosi

A. L. Harkness (25)

R. Avery

L. Burris

A. B. Shuck

D. W. Cisse1

M. J. Ryan

S. A. Davis

C. M. Walter

B. R. T. Frost

R. M. Fryer

D. C. Rardin

M. H. Derbidge

R. G. Staker

L. C. Walters

R. J. Teunis

A. B. Krisciunas

C. E. Till ANL Contract File

R. S. Zeno

ANL Libraries (5)

TIS Files (6)

\section{External:}

ERDA-TIC, for distribution per UC-15 (328)

Manager, Chicago Operations Office

Chief, Chicago Patent Group

S. Kops, ERDA-CH

R. E. Lang, ERDA-CH

J. L. Jaech, Exxon Nuclear Co.

K. B. Stewart, Pacific Northwest Labs.

S. C. Suda, Brookhaven National Lab.

R. H. Moore, USNRC, Washington

Director, Reactor Programs Div., ERDA-CH

Director, CH-INEL

President, Argonne Universities Association 